\title{
The Effect of State Banking Laws on Holding Company Banks
}

\author{
DONALD M. BROWN
}

\begin{abstract}
$\mathrm{B}$
ANK holding companies are subject to a variety of state banking laws that govern the extent of branch banking and the number of banks that can be owned. In response to different legal environments, significant differences may result between the reported operating results of independent banks and holding company banks; as one consequence, bank financial ratios may be affected significantly by state banking laws. ${ }^{1}$ These financial ratios include measures of bank profitability, efficiency and portfolio composition. Variables representing the characteristics of a bank's market also may be affected by state banking laws. These market variables include measures of market structure, size and growth.
\end{abstract}

This article has two purposes. The first is to determine whether bank financial ratios and market variables are related to bank holding company ownership or state laws limiting the number of banks owned by any one holding company. The second is to determine whether there are significant economic incentives favoring the formation of multi-bank holding companies over one-bank holding companies.

\section{WhI DO BAN WOE WODNG COMPANIES WEST?}

Bank holding companies have specific advantages over independent banks. They generally avoid being

\footnotetext{
${ }^{1}$ Bank financial ratios have been examined extensively by economists. A lengthy bibliography of this literature, including citations through part of 1978, may be found in Ronald $\mathrm{L}$. Schillereff, Multibank Holding Company Performance (UMI Research Press, 1982).

As used herein, "state banking laws" refer specifically to state kaws governing branch banking and bank holding companies.
}

taxed on internal dividend payments, they can engage in a wider range of non-banking activities, they are less hampered by geographical restrictions, and they can raise funds by selling the commercial paper of the parent corporation; they also can circumvent state branching restrictions. These advantages are more important to some bank holding companies than to others; likewise, they are more fully realized by owning some banks rather than others. The economic value of these advantages is reflected in the prices that holding companies offer for different banks.

If the costs associated with holding company ownership were low relative to the potential gains, all banks would be owned by holding companies. This, of course, is not the case. Bank holding companies incur a variety of costs: regulatory, administrative, even the one-time cost of getting permission to acquire banks. A bank will remain independent until the discounted present value of the advantages of holding company ownership outweigh the discounted present value of the costs.

Regardless of the number of banks they own, all holding companies are subject to the same federal regulations. Consequently, any gain realized by multibank holding companies must be associated with ownership of the banks themselves; it is not related to the profits associated with the permissible range of non. bank activities.

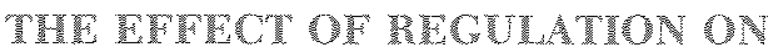 PADK HOZ ONG COMPANGS

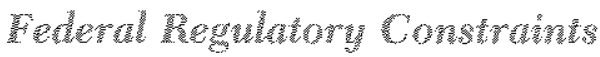

Federal regulatory policy may prevent multi-bank holding companies from owning certain banks. The 


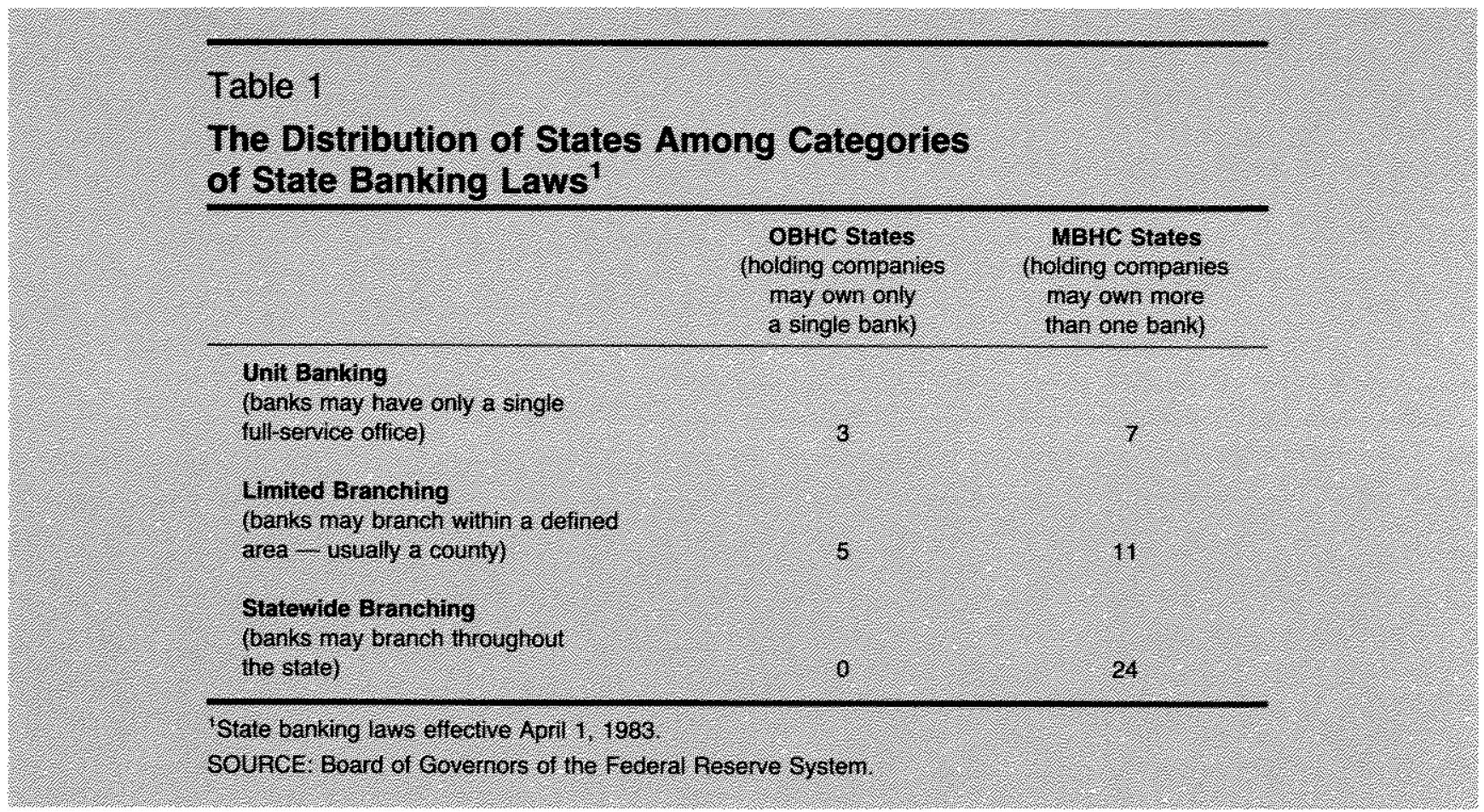

Board of Governors of the Federal Reserve System is likely to prevent an acquisition by a multi-bank holding company if that company already has a large market share or if the acquisition would substantially increase concentration in a banking market. The Board also may prevent acquisitions or holding company formations for reasons other than competition. For example, it may rule unfavorably if the holding company is thought to be financially weak. Consequently, some banks may be either independent or owned by one-bank holding companies solely because of actual or anticipated regulatory denials.

\section{The Adeptation of Bank Holding Companies sto State Banking Laus}

State banking laws also may affect bank ownership Table 1 categorizes states according to their restric tions on branching and bank holding companies and shows the distribution of the 50 states among these categories. If the legal constraints imposed by state laws are binding, banks and bank holding companies will attempt to circumvent them. ${ }^{2}$ Multi-bank holding

${ }^{2}$ We cannot know the effect of a constraint with certainty until it is removed; however, the existence of unit banks and one-bank holding companies in states that allow both statewide branching and multi-bank holding companies is strong circumstantial evidence that state banking laws are not binding on all organizations. companies represent one way to circumvent the state branching restrictions described in table 1.

In unit-banking and limited-branching states that permit multi-bank holding companies, bank holding companies are not constrained to own only one bank; each one-bank holding company does so by choice. Because both one-bank and multi-bank holding companies exist simultaneously in these states, their owners must face different incentives. Consequently, they may own different types of banks or manage their banks in ways that produce different operating results and portfolio compositions.

Any prohibition of branching is more effective if multi-bank holding companies also are prohibited. ${ }^{3}$ Even though some holding companies in states prohibiting both types of organizations might wish to own only one bank, others would choose to own more banks in the absence of the constraint. The constrained and unconstrained one-bank holding companies in these states may have different financial and market characteristics.

In states that allow statewide branching, both branch banks and multi-bank holding companies

\footnotetext{
${ }^{\text {Table }} 1$ offers some circumstantial evidence. None of the 24 states that allow statewide branching prohibit multi-bank holding companies. Apparently, once banks are allowed to branch throughout a state, preventing holding companies from owning more than a single bank is not an effective constraint.
} 
potentially can achieve the same geographic scope. ${ }^{4}$ Consequently, multi-bank holding companies and one-bank holding companies that own branch banks may not display significant differences in terms of their financial and market characteristics. On the other hand, there may be significant differences between a one-bank holding company that owns a branch bank and another in the same state that owns a unit bank.

\section{Distortions of Reported Financial Results}

Differences in reported financial characteristics do not necessarily reflect actual operating differences. Comparisons of the financial ratios of unit and branch banks, whether located in the same or different states, are distorted by financial reporting conventions. Because the financial results of a bank's branches are aggregated for reporting purposes, differences between the reported financial characteristics of branch and unit banks may be due partly to lumping differentsized branches in different locations into a single reporting entity. The problem exists if the state allows limited or statewide branching. It is compounded in branching states that allow multi-bank holding companies because a multi-bank holding company (subject to regulatory approval) may choose either to charter a subsidiary bank separately or make it the branch of another subsidiary bank. Thus, the reported financial characteristics will depend upon the permissible legal forms.

\section{Is There an Economic Incentue for Multi-Bank Iolding Companies?}

Although it might be argued that the existence of multi-bank holding companies is prima facie evidence that some companies have an economic incentive to own more than one bank, multimbank holding companies could arise by chance. Assume, for example,

\footnotetext{
${ }^{4}$ Federal law effectively prevents interstate branching and interstate banking expansion by holding companies. States can extend a statutory invitation to out-of-state bank holding companies, but only a handful actually have done so. Alaska allows ont-of-state companies to buy Alaskan banks that have operated for at least three years. Maine, Massachusetts and New York permit holding companies from states that reciprocate; the Massachusetts law limits reciprocity to only New England states. Washington allows out-of-state holding companies to purchase banks in the state that are in financial difficulty. Finally, Delaware and South Dakota allow out-of-state holding companies to own special-purpose banks, which are operated under nules that prevent them from actively soliciting deposits from the publie. (Information on these state laws was provided by the staff of the Board of Governors of the Federal Reserve System.)
}

that owning two or more banks conferred no net gain to a bank holding company. It should then make no difference whether a bank is owned by a one-bank or multibank holding company. Even if banks with certain observable characteristics typically are owned by bank holding companies, any specific holding company could hold either one or several of these banks. In this example, whether a bank is owned by a holding company depends upon the bank's own observed financial and market characteristics alone.

Assume, now, that some bank holding companies derive some net advantage from owning several banks. These advantages may arise from the nature of either the bank or the bank holding company; they are distinct, however, from the advantages realized by onebank holding companies. Under this assumption, multi-bank holding companies would own some banks that would not be owned by one-bank holding companies. Therefore, a bank's chance of being owned by a holding company would depend on state laws regarding multibank holding companies, as well as its individual financial and market characteristics.

We cannot say a priori that there are economic incentives for some bank holding companies to own several banks. The issue must be decided on the basis of empirical evidence. Although a variety of empirical tests could be chosen, the tests used in this article focus on the relationship between bank holding company ownership and a bank's financial and market characteristics in unit-banking states. ${ }^{5}$

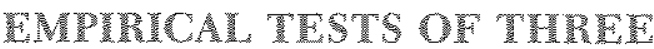

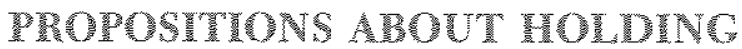 COMPANY BANKS TR UNIT-DANKING STARS}

Three testable propositions regarding certain bank characteristics in unit-banking states can be derived

\footnotetext{
${ }^{5}$ Since this study is confined to a sample of banks from unit-banking states, it does not provide direct evidence on whether multi-bank holding companies circumvent state branching restrictions. A worthwhile direction for future research would be to expand the sample to include banks from states that allow limited and statewide branch banking. Empirical tests on the expanded sample could determine whether the incentives of multi-bank holding companies are reduced or eliminated in states having less stringent restrictions on branching

This study atso does not explore the nature of the economic incentive to own several barks. The evidence presented in the next section indicates that, whether the incentive arises from cost advantages, control over price or some other souree, it is apparent Iy quite strong. Another worthwlile direction for fature research would be to investigate its source.
} 
from the preceding discussion:

1. The financial and market characteristics of banks owned by multi-bank holding companies will differ from those of other banks.

2. The financial and market characteristics of banks owned by one-bank holding companies will differ from those of other banks; they will depend on state laws regarding multi-bank holding companies.

3. A bank is more likely to be owned by a holding company if the state permits multi-bank holding companies.

\section{Methodology and Sample Characteristics}

These propositions are tested by probit analysis to estimate the effect of certain independent variables on the likelihood that a bank is owned by a bank holding company. ${ }^{6}$ The following are the dependent variables in three probit regression models, each of which represents a choice between alternative forms of ownership:

$$
\begin{aligned}
Y_{1}= & 1, \text { if a bark is owned by a multi-bank holding } \\
& \text { company, } \\
= & 0, \text { otherwise; } \\
Y_{2}= & 1, \text { if a bank is owned by a one-bank holding } \\
& \text { company, } \\
= & 0 \text {, otherwise; } \\
Y_{3}= & 1 \text {, if a bank is owned by either a one-bank or } \\
& \text { multi-bank holding company, } \\
= & 0, \text { otherwise. }
\end{aligned}
$$

The sample on which the probit models are estimated consists of all insured commercial banks in six western and midwestern unit-banking states. The sample is divided into two subsamples of three states. States in one subsample permit multi-bank holding companies; states in the other prohibit them. ${ }^{7}$ Any holding company that owns two or more banks in any state is defined as a multi-bank holding company; the others are one-bank holding companies.

Four probit regression equations are estimated for each of the years 1978 and 1981 . The $Y_{1}$ model is

\footnotetext{
${ }^{6}$ Probit analysis is a non-linear estimation technique frequently used when a model's dependent variable represents the choice between two alternatives. For explanations of the probit model, see Robert S. Findyck and Daniel $L$. Rubinfeld, Econometric Models and Economic Forecasts, and ed. McGraw-Hill Book Company, 1981), pp. 280-87; and George G. Judge and others, The Theory and Practice of Econometrics (John Wiley and Sons, 1980), pp. 591-92.

${ }^{7}$ In the six states used in this study, Colorado, Missouri and Wyoming permit multi-bank holding companies; Kansas, Nebraska and Oklahoma prohibit them.
}

estimated on the subsample permitting multi-bank holding companies; the $\mathrm{Y}_{2}$ model is estimated separately on each subsample; and the $Y_{3}$ model is estimated on the full sample.

\section{Indenendent Warinbles}

Table 2 defines the independent variables used in the probit models and reports their summary statistics for both 1978 and $1981 .^{8}$ The same financial variables have been used in many empirical studies that have investigated differences between independent and holding company banks. These variables were constructed from financial data in annual bank call reports and income statements for the years ending December 31, 1978, and December 31, 1981. The variables measuring market characteristics were computed by aggregating bank financial data across banking markets, which were defined as either Standard Metropolitan Statistical Areas (SMSAs) or counties (in the case of counties not part of SMSAs).

A comparison of the variables' means in 1978 and 1981 shows that the ratios of operating expense and net federal funds sold to total assets (ROE and RNFFS) were markedly higher in 1981, and the ratio of total loans to total assets (RTL) was lower in 1981. These differences may be explained by the economic conditions prevailing in 1981, when interest rates reached historically high levels and loan demand (partly reflective of interest rates) was low. Increases in the means of dummy variables SMSA and MBHC between 1978 and 1981 indicate increases in the proportion of sample banks located in SMSAs and states that allow multi-

\begin{tabular}{|c|c|c|c|}
\hline $\begin{array}{c}1978 \\
\text { Correlations }\end{array}$ & $\begin{array}{c}\text { OBHC } \\
\text { Subsample }\end{array}$ & $\begin{array}{c}\text { MBHC } \\
\text { Subsample }\end{array}$ & Full Sample \\
\hline ROE, RNE & 0.41 & -0.41 & 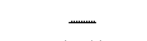 \\
\hline CR, SMSA & -0.42 & -0.61 & -0.50 \\
\hline CR, DCRMBHC & $\ldots$ & $m$ & 0.41 \\
\hline MBHC, DCRMBHC & - & - & 0.55 \\
\hline $\begin{array}{c}1981 \\
\text { Correlations }\end{array}$ & $\begin{array}{c}\text { OBHC } \\
\text { Subsample }\end{array}$ & $\begin{array}{c}\text { MBHC } \\
\text { Subsample }\end{array}$ & Full Sample \\
\hline ROE, RNI & -0.48 & 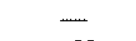 & - \\
\hline CR, SMSA & -0.43 & -0.63 & -0.51 \\
\hline CR, DCRMBHC & - & - & 0.41 \\
\hline MBHC, DCRMBHC & - & - & 0.56 \\
\hline REQ, RNFFS & - & 0.42 & - \\
\hline
\end{tabular}
}
bank holding companies.

\footnotetext{
${ }^{8}$ Some independent variables were considered for inclusion in the models but were dropped because they were highly correlated with other independent variables. In each subsample and in the full sample, most simple correlations between included independent variables were less than 0.20 in absolute value in both 1978 and 1981 . The simple correlations exceeding 0.40 are reported below: 


\section{Table 2}

\section{Definitions and Summary Statistics of Independent Variables}

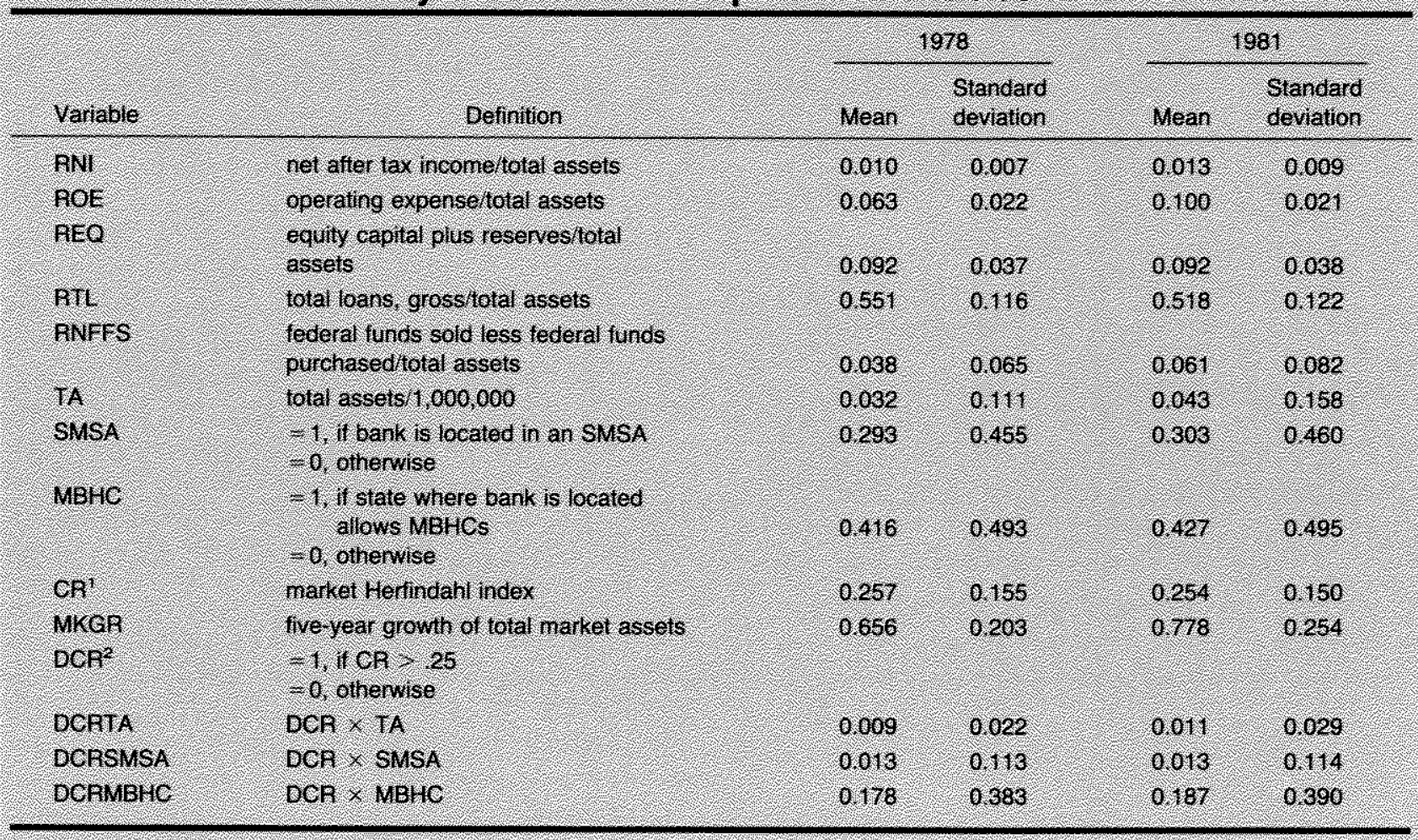

The incex is calculated on the basis of shares of total assets:

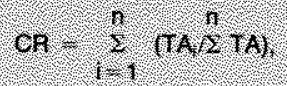

Where TA is he tolal assets of the ith banking organization in the natket Note that $0.6 \mathrm{CR}-1$.

The variable DCh was not heluded in the probil modes because II is highly correlated with ch It does enter in the three interaction vatiables.

A positive (negative) sign on an independent variable's coefficient indicates that higher values of the variable increase (decrease) the likelihood that a bank is owned by the specified type of bank holding company. The coefficient of TA is expected to be positive in the $Y_{1}$ model. This expectation is based not on theory, but on previous empirical study. ${ }^{9}$ It assumes that as a bank's size increases, ceteris paribus, the likelihood that the bank is owned by a multi-bank holding company also increases.

No predictions can be made as to the signs of other coefficients in the $Y_{1}$ and $Y_{2}$ models. Although many

\footnotetext{
${ }^{9}$ Multi-bank holding companies tend to own larger banks. Many of these organizations own lead banks that are among a state's largest banks. Subsidiary banks other than lead banks often are larger than the average bank in their markets and seldom are among the very small banks.
}

empirical studies have investigated the relationship between holding company ownership and bank financial ratios, they have potentially important weaknesses, including a nearly universal failure to control for the potential effects of diverse state banking laws. Moreover, they frequently have produced conflicting results.

The variables MBHC and DCRMBHC are included in only the $\mathrm{Y}_{3}$ model. ${ }^{10}$ As the following section explains, the estimated coefficient of MBHC is predicted

\footnotetext{
${ }^{10}$ In the subsample on which the $\mathrm{Y}_{1}$ and first $\mathrm{Y}_{2}$ models were estimated, MBHC took on the value of 1 for all observations, while DCRMBHC took on the value of 1 or zero. In the subsample on which the second $\mathrm{Y}_{2}$ model was estimated, both variables took on the value of zero for all observations.
} 
to be positive, and the estimated coefficient of DCRMBHC is predicted to be negative.

\section{The Criteria for Accopting or Rejecting whe Propositions}

The first proposition is "accepted" (in the statistical sense) if the likelihood ratio of the $Y_{1}$ estimation is statistically significant in both 1978 and 1981. This would indicate that, in unit-banking states that permit multi-bank holding companies, banks owned by multibank holding companies differ from other banks on the basis of their financial and market characteristics.

For the first proposition to be accepted, neither the sizes, statistical significance, nor the signs of the estimated coefficients need to be invariant over the two years. Coefficients may differ between 1978 and 1981 because changing economic conditions affected multibank holding company subsidiaries and other banks differently; because the modest increase in the total number of banks and/or the proportionately large increase in multi-bank holding company subsidiaries occurring in the subsample between 1978 and 1981 (see tables $3 \mathrm{a}$ and $3 \mathrm{~b}$ ) altered the compositions of the two groups of banks; because the financial and market characteristics of the two groups of banks are following different long-term trends; or for a combination of these reasons. None of these possibilities would obviate the conclusion that banks owned by multi-bank holding companies differ from other banks.

The second proposition is accepted if in both 1978 and 1981, the likelihood ratios of the two $\mathrm{Y}_{2}$ estimations are statistically significant and if the signs or statistical significance of the coefficients differ between the two estimations. The former would show that onebank holding company banks differ from other banks in their financial and market characteristics, regardless of whether multi-bank holding companies are permitted. The latter would show that the financial and market characteristics of one-bank holding company banks depend on whether a state allows or prohibits multi-bank holding companies. Differences in financial and market characteristics between one-bank holding company banks in the two subsamples would be the result of differences between constrained and unconstrained holding companies in the states that prohibit multibank holding companies. Like the first proposition, the second proposition is not refuted by different coefficient estimates in the 1978 and 1981 estimations.

The coefficients in the $Y_{1}$ and $Y_{2}$ estimations can be compared in the same manner. If, in states that allow multi-bank holding companies, the signs or statistical significance of the coefficients differ between the $\mathrm{Y}_{1}$ and $Y_{2}$ estimations, then banks owned by the two types of holding companies have different financial and market characteristics.

The third proposition depends on the coefficient of $\mathrm{MBHC}$ in the $\mathrm{Y}_{3}$ estimation. It is accepted if the estimated coefficient is positive and significantly greater than zero in both 1978 and 1981. A positive sign would indicate that, given its financial and market characteristies, a bank is more likely to be owned by a bank holding company (either a one-bank or multi-bank holding company) if it is located in the unit-banking states that permit multi-bank holding companies.

The interaction variable DCRMBHC is included in the $\mathbf{Y}_{3}$ model to account for the possible effect of federal regulation on the likelihood of holding company ownership. The Board of Governors is more likely to prevent acquisitions by multi-bank holding companies in highly concentrated markets $(D C R=1$ ) than in less concentrated markets (DCR $=0$ ); therefore, the coefficient of DCRMBHC is predicted to be negative in both 1978 and 1981.

\section{Empiricol Results}

$Y_{I}$ Estimations - The results of the $Y_{1}$ estimations are reported in column 1 of tables $3 \mathrm{a}$ and $3 \mathrm{~b}$. Both likelihood ratios are highly significant, indicating that banks owned by multi-bank holding companies differ from other banks in terms of the independent variables included in the $Y_{1}$ model. Moreover, most estimated coefficients also are statistically significant, which indicates that the corresponding independent variables are different for multi-bank holding company subsidiaries than for other banks.

Several coefficients had the same sign and were statistically significant in both years. The estimated coefficients of TA are positive and statistically significant, as predicted. The results also show that, even after controlling for the influence of bank size (TA), banks owned by multi-bank holding companies are located more often in metropolitan areas and less concentrated banking markets. The positive coefficients on the interaction variable DCRTA imply that, ceteris paribus, a larger bank in a highly concentrated market is more likely to be owned by a multi-bank holding company than a smaller bank in the same market.

Other coefficients differed between the two years. In 1978, banks owned by multi-bank holding com 
Table 3a

Coefficient Estimate Results of Probit Analysis (1978) (t-statistics in parentheses)

\begin{tabular}{|c|c|c|c|c|}
\hline Ifor & $\begin{array}{l}40, \\
4010\end{array}$ & $\begin{array}{l}(9) \\
m p e r\end{array}$ & $\begin{array}{l}(3) \\
\text { subsic } \\
\text { subsemple? }\end{array}$ & $\begin{array}{l}(4) \\
\text { mull } \\
\text { sample }\end{array}$ \\
\hline Variables & Y & $y_{2}$ & $y_{3}$ & Y. \\
\hline \multicolumn{5}{|c|}{ Fnanciol varibles } \\
\hline 911 & $-12,69$ & $475^{\circ}$ & $\begin{array}{l}30.57^{\circ} \\
4.85]^{\circ}\end{array}$ & $\begin{array}{l}9.97 \\
1248\end{array}$ \\
\hline not & $(2.56$ & $\frac{16,79}{(301)}$ & $(-1.60)$ & $(-(-2)$ \\
\hline AEO & 0.24 & $(-2.881)$ & $(-14.21)^{*}$ & $(-3-3,161$ \\
\hline III & $\begin{array}{c}201 \\
(600)\end{array}$ & $\begin{array}{r}0.14 \\
0.87)\end{array}$ & $(5.89)$ & $(1.92 \%$ \\
\hline RUFrs & $(-205)$ & $\begin{array}{l}162 \\
(194)\end{array}$ & $(-1,136)$ & $(-0.97)$ \\
\hline 14 & $(7.68)$ & $(.090)$ & $(3.17)^{2}$ & $(6.4)^{6}$ \\
\hline \multicolumn{5}{|c|}{ Threl yoribles } \\
\hline SWSA & $\left(3.44^{*}\right.$ & $\begin{array}{l}0.12 \\
(0.85)\end{array}$ & $\begin{array}{r}0.26 \\
(-2.49)\end{array}$ & $(1.18)$ \\
\hline WE16 & & & & $(6.46)$ \\
\hline Cl. & $\left(\begin{array}{l}17 \\
272)\end{array}\right.$ & $(2.98)$ & $\begin{array}{l}0.16 \\
(0.59)\end{array}$ & $\begin{array}{l}0.16 \\
(0.76)\end{array}$ \\
\hline Mkan & $\begin{array}{l}020 \\
(1,17)\end{array}$ & $(026)$ & $(-1,58$ & $(-2.41)$ \\
\hline $\mathrm{MOFT}$ & $(2,18)$ & $\begin{array}{l}-2.77 \\
(-0.66)\end{array}$ & $(-0.07)$ & $(2,02)$ \\
\hline Dopsus & 0.69 & $(0.66)$ & $\begin{array}{r}0,13 \\
(042)\end{array}$ & $\begin{array}{l}0,29 \\
(1,18)\end{array}$ \\
\hline Doninsile & & & & $(-0.35$ \\
\hline constont & $(-3.50)^{\circ}$ & $\left(\begin{array}{l}209 \\
(454)\end{array}\right.$ & $(0.6)$ & $\left(\begin{array}{l}126) \\
(575)\end{array}\right.$ \\
\hline rikelinood & 221.01 & 4577 & & $34892^{*}$ \\
\hline $11^{6}$ & 1.101 & 1,101 & 1546 & 2.647 \\
\hline$y=1$ & 369 & 181 & 529 & 1,100 \\
\hline
\end{tabular}

Signiticant at 5 percent confotence level

r Significant at 1 percent conifidence level:

SStates that bermit nuil bant holding companies.

States that prohibit muti bank holding companies.

Sumber of observations.

'Number of observations on the dependent Variables $Y_{\text {, }}$, or Y, at 1 Oher obsenvations al zero. The numbers do nol add across becaise there are 21 subsidiary banks of mulf bank holding cempanies in the one bank holding conpany subsample? 
Table $3 b$

Coefficient Estimate Results of Probit Analysis (1981) (t-statistics in parentheses)

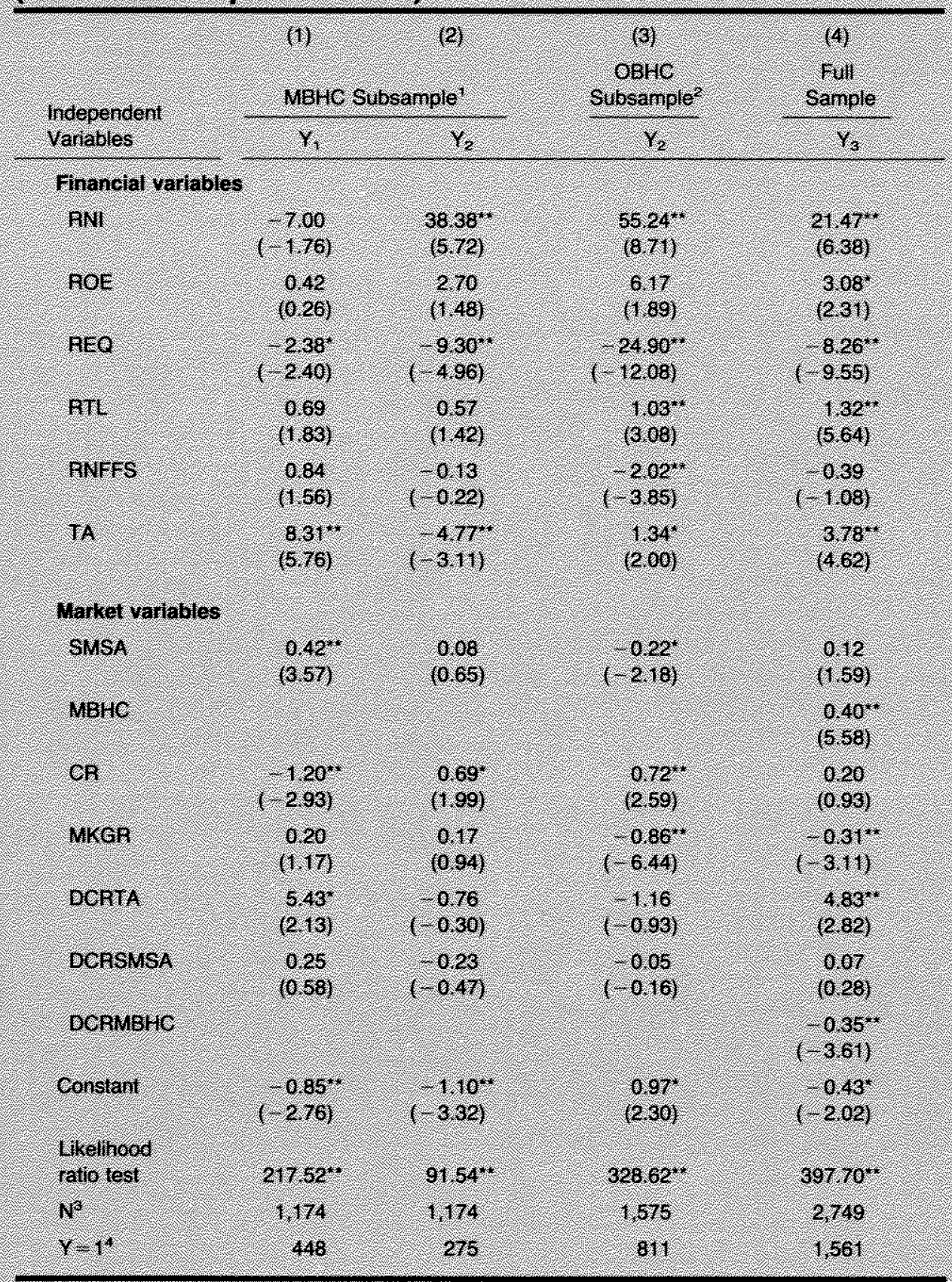

Signilicant at 5 percent contidence level

* Sigriffeant at 1 percent contidenee level.

SStates that permil nulit bain holding companes.

States that prohibi nutibank holding companies

Number of observations:

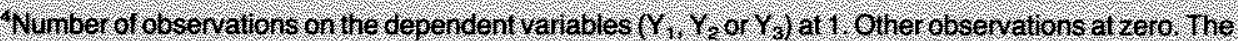
numbers do nol add across because here are 27 substiliz banks or mult bank holding companies in the one-bank holding company subsample. 
panies devoted a larger share of their portfolios to loans and sold fewer net federal funds as a proportion of total assets, while their ratios of equity to total assets did not vary significantly from other banks. On the other hand, in 1981, these banks had significantly lower ratios of equity to total assets, while the share of their portfolios devoted to loans and net federal funds sold did not vary significantly from other banks.

$Y_{2}$ Estimations - The $Y_{2}$ estimations are reported in columns 2 and 3 of tables $3 \mathrm{a}$ and $3 \mathrm{~b}$. The highly significant likelihood ratios indicate that, regardless of state policy toward multi-bank holding companies, banks owned by one-bank holding companies differ from other banks.

In 1978 , the estimated coefficients of the financial variables had uniformly opposite signs and statistical significance in columns 1 and 2 (see table 3a). The differences between the columns were fewer in 1981 . Banks owned by one-bank holding companies earned a higher return on total assets than other banks in 1981, whereas the return of banks owned by multi-bank holding companies did not vary significantly from other banks; furthermore, multi-bank holding company subsidiaries tended to be larger than other banks, and one-bank subsidiaries tended to be smaller (see table $3 \mathrm{~b}$ ). The findings indicate that one-bank and multi-bank holding companies had different financial ratios in the states that permit multi-bank holding companies.

The estimated coefficients of the market variables are similar in both 1978 and 1981. In column 2 of the tables, the estimated coefficients of market concentration (CR) are positive and significant, whereas in column $I$ the coefficients of CR are negative and significant. This difference implies that banks owned by onebank holding companies tend to be located in more concentrated markets, while banks owned by multibank holding companies tend to be located in less concentrated markets. The estimated coefficients of the other market variables in column 2 are not statistically significant.

A comparison of column 3 with columns 1 and 2 in the tables shows that banks owned by one-bank holding companies in unit-banking states that prohibit multi-bank holding companies exhibit similarities to both types of holding companies in the other subsample of states. In column 3 , the estimated coefficients of all financial variables, except ROE, are statistically significant at the 5 percent confidence level or better. In 1978, they took the sign of the estimated coefficient from column 1 or 2 that had the $t$-statistic of larger absolute value. In 1981, this was the case for the estimated coefficients of RNI and TA; estimated coefficients of other financial variables were either statistically insignificant in columns 1 and 2 (ROE, RTL, RNFFS) or they had the same sign (REQ). Apparently, some holding company banks in the states that prohibit multi-bank holding companies have similar financial characteristics to one-bank holding company subsidiaries in those states that permit multi-bank holding companies; others have similar financial characteristics to multi-bank holding company subsidiaries. This interpretation is consistent with the characterization, in the preceding section, of one-bank holding companies in this subsample as either constrained or unconstrained organizations.

The estimated coefficients of the market variables do not exhibit the same pattern. In column 3 , only the negative estimated coefficients of the dummy variable representing metropolitan markets (SMSA) and the market growth variable (MKGR) were statistically significant in both 1978 and 1981. The latter was not significant in either of the other estimations, and the former was significant but positive in the $Y_{1}$ estimations. In 1981, the estimated coefficient of CR in column 3 was statistically significant, taking the positive sign of the coefficient estimate in column 2.

$Y_{3}$ Estimations - The $Y_{3}$ estimations are reported in column 4 of tables $3 \mathrm{a}$ and $3 \mathrm{~b}$. The high likelihood ratios indicate that holding company banks, as a group, can be distinguished from independent banks on the basis of the independent variables. The positive and highly significant estimate of the MBHC coefficient in both 1978 and 1981 strongly supports the third proposition. The negative and highly significant estimate of the DCRMBHC coefficient in both 1978 and 1981 confirms the prediction that, ceteris paribus, banks in highly concentrated markets are less likely to be owned by a holding company if the state permits multibank holding companies.

\section{CONGUSONS}

One-bank and multi-bank holding company subsidiaries in unit-banking states have different financial and market characteristics than other banks. Moreover, the characteristics of the one-bank holding company banks depend on state laws regarding multi-bank holding companies. In addition, a bank is more likely to be owned by a holding company in unit-banking states that permit multi-bank holding companies than in unit-banking states that prohibit them. 
These results clearly imply that empirical studies that examine the effects of holding company ownership on bank financial ratios should control for differences among state banking laws, as well as for differences between one-bank and multi-bank holding companies. Though this may not appear to be a startling conclusion, recent studies have failed to control for one or both of these differences. ${ }^{11}$ Future studies will have to do so if they are to correctly assess the factors that cause financial and market characteristics to differ among banks.

"Johnson and Meinster, Jackson, and Mayne fail to control for differences in state laws, while Fraas fails to account for differences between one-bank and multi-bank holding companies; Rose and Scott, and Graddy and Kyle, fail on both counts. Only Mingo accounted for both, by limiting his sample to nine unit-banking states that permit multi-bank holding companies and excluding subsidiary banks that were owned by one-bank holding companies. By limiting his sample in this way, the author also avoided the aggregation problem with comparing the financial results of unit and branch banks. See Rodney $D$. Johnson and David $R$. Meinster, "The Performance of Bank Holding Company Acquisitions: A Multivariate Analysis," Journal of Business (April 1975), pp. 204-12; William Jackson, "Multibank Holding Companies and Bank Behavior" (Working Paper 75-1, Federal Reserve Bank of Richmond, July 1975); Lucille S. Mayne, "A Comparative Study of Bank Holding Company Affiliates and Independent Banks, 1969-1972,"Journal of Finance (March 1977), pp. 147-58; Arthur G. Fraas, The Performance of Individual Bank Holding Companies, Staff Economic Studies 84 (Board of Govemors of the Federal Reserve System, 1974); Peter S. Rose and William L. Scott, "The Performance of Banks Acquired by Holding Companies," Review of Business and Economic Research (Spring 1979), pp. 18-37; Duane B. Graddy and Reuben Kyle, III, "Affiliated Bank Performance and the Simultaneity of Financial Decision-Making "Journal of Finance (September 1980), pp. 951-57, and John J. Mingo, "Managerial Motives, Market Structures and the Performance of Holding Company Banks," Economic Inquiry (September 1976), pp. 411-24. 